\section{BERNARD}

\section{QUARITCH}

LIMITED

\section{Antiquarian Booksellers}

since 1847

RARE BOOKS on

MEDICINE, NATURAL

HISTORY AND OTHER

SCIENCES

Catalogues issued

II GRAFTON STREET NEW BOND STREET

W.I HYD 0022
THE SORBY CENTENNIAL SYMPOSIUM ON

THE HISTORY OF METALLURGY

\author{
Edited by
}

C. S. SMITH

Metallurgical Society Conferences

vol. 27

This symposium was held to celebrate the 100 th anniversary of the discovery of the microstructure of steel by the great scientist, Henry Clifton Sorby.

$584 \mathrm{pp}$. illustrated. $\quad$ f7 16s.

published by

GORDON \& BREACH SCIENCE

PUBLISHERS INC., New York

distributed throughout the U.K., British

Commontwealth and Europe by

BLACKIE \& SON LIMITED

5 Fitzhardinge Street, London W.1

The British Society for the History of Science

\title{
Student Membership
}

A new class of membership has been instituted by the Society, under the title Student membership.

"Students" of the Society must normally be below the age of 25 years and be undergoing a full- or part-time course of education at a school, college or university.

The Annual Subscription for "Students" is $£ 110$ s. 0d. ( $\$ 4.50$ U.S.).

Student membership entitles the holder to receive Parts of the Society's journal, as these are published, without additional charge, and to receive all the other privileges of Ordinary Membership, except a vote in matters affecting the running of the Society.

Further information about the Society will be found on the inside back cover of this journal. 


\section{British Men of Science}

general editor Sir GAVIN de BEER

\section{EDMOND HALLEY}

\section{ANGUS ARMITAGE}

Dr. Armitage combines an historical evaluation, more elaborate than any previously undertaken, of Halley's scientific researches, particularly as they are presented in the Philosophical Transactions, with a complete account of his life and varied careers.

20 pages of half-tones, 28 line drawings $42 s$.

\section{GHARLES \\ SCOTT SHERRINGTON}

RAGNAR GRANIT

Professor Granit first describes the kind of physiology of the nervous system Sherrington found in his youth, then assesses Sherrington's own achievements and their relevance to modern neurophysiology. A view of the man as well as the scientist. 16 pages of half-tones $42 \mathrm{~s}$.

\section{ALMROTH WRIGHT}

\section{Sir ZACHARY COPE}

The life and work of an innovator of genius. Wright introduced anti-typhoid inoculation and vaccine therapy; he was also a pioneer in the creation of institutes for medical research. 12 pages of half-tones, 11 figures June $42 \mathrm{~s}$.

\section{四 NELSON}




\section{CAMBRIDGE}

\section{The History of Cell Respiration and Cytochrome \\ DAVID KEILIN. Edited by JOAN KEILIN}

A personal and historical account of the development of the concept of intracellular respiration, from Galen to the present day, and the study of cytochromes. Professor Keilin discusses in particular MacNunn's discovery of histohaematin, the work leading up to the discovery of cytochrome and subsequent studies of it.

90s. net.

\section{The Mathematical Practitioners of Hanoverian England, 1714 - 1840}

E. G. R. TAYLOR

This book contains both a general study of the work of the Hanoverian mathematical practitioners, set against their social and historical background, and a catalogue giving both biographical and bibliographical details of over 2,200 practitioners who flourished in this period. It is a sequel to Professor Taylor's Mathematical Practitioners of Tudor and Stuart England, which is shortly to be re-issued.

84 s. net.

\section{CAMBRIDGE UNIVERSITY PRESS}




\section{CASSELL}

TECHNICAL BOOKS

Recently published:

SEIENCE, HISTORY \& TECHNOLOGY Book 1: 800-1840's

\section{MAURICE GOLDSMITH}

Member of Central Executive of the W.E.A., Director of the Science Information Service, Chairman of Advisory Committee of Guinness Awards for Science

Teachers, Tutorial Lecturer on Science at London University.

\section{H. J. FYRTH}

Science Tutor in History and Economics in the Extra Mural Department of London University, he has a special interest in Trade Union Education.

These two authors have used their very considerable knowledge and understanding of science and history to explain how man's changing patterns of behaviour have affected, and been affected by, the increasingly rapid advancement of science and technology. In the words of a recent reviewer, "It is scholarly, but exciting and readable... it gives not only a knowledge of history and technology but a feeling for them too".

272 pages, many photographs, line drawings. 25/-.

GASSELL 35 Red Lion Square, London, WC1

\section{P'HIYYSIIS}

Quarterly Review of the History of Science

Founded in 1959 by:

Domus Galilaeana (Pisa), Istituto e Museo di Storia della Scienza (Florence), Museo Nazionale della Scienza e della Tecnica (Milan); Gruppo Italiano di Storia della Scienza.

Published under the auspices of the Consiglio Nazionale delle Ricerche.

\section{ARTICLES:}

\section{Contents of Year VII (1965), Fasc. 1.}

R. SAvelli: Giovan Battista Amici, botanist. (On the first centenary of his death.)

G. Arrighi: Lettere di G. B. Amici nelle Bibliotheche di Forli e di Lugo. J. NEEDHAM and G. D. Lu: A further note on efficient equine harness; the Chinese inventions.

I. CAPASSO: L'Astronomia nella Divina Commedia.

F. KATSCHER: "Diophantische" kubische Gleichungen. NOTES:

G. VARANINI: Uno sconusciuto autografo galileiano.

Book Reviews - News - Publications Received Annual subscription (4 issues)-4,500 lire (Italy), \$11.00 (abroad). 


\section{THE GONGEPT OF ENERGY}

ITS SIGNIFICANCE IN

FUNDAMENTAL THEORY AND PRACTICE

\section{$D W$ THEOBALD}

This book, says Dr Theobald, is emphatically not a textbook on energy. It is rather an attempt to help us understand the concept of energy in the natural sciences. The uses of the term, its development with the increase in technological knowledge, its various roles today, are all discussed, and the possible physical reality of energy is considered.

All those for whom the concept of energy is a working tool will welcome this admirably lucid investigation.

$42 s$

E \& F N SPON 11 New Fetter Lane London EC4 


\section{THE BRITISH SOGIETY FOR THE HISTORY OF SGIENCE}

THE objects of the Society are to further the study of the history of science, by holding meetings for the reading and discussion of papers, and by facilitating the publication of relevant material.

The British Fournal for the History of Science is the official organ of the Society.

Meetings are held in the Science Museum, Exhibition Road, South Kensington, London, S.W.7, usually in October, November, March and May. In addition a Winter Meeting is held in January and a Summer Meeting in June; neither of these meetings is necessarily held in London.

Membership is open to all persons approved by the Council of the Society, and elected at an Ordinary Meeting. The annual subscription is at present $£ 2$ Ios. (for Students $£_{1}$ I ros.) and includes a free issue of the Society's Journal, which appears in June and December each year.

Those who wish to join the Society should write to the Hon. Secretary, Mr. J. A. Chaldecott, Science Museum, South Kensington, London, S.W.7.

Papers for inclusion in the Journal should be submitted to the Hon. Editor, Dr. M. P. Crosland, Department of Philosophy, The University, Leeds 2, from whom instructions may be obtained concerning the presentation and documentation of papers. All communications on editorial matters, and books for review, should be addressed to the Hon. Editor.

Particulars regarding advertising in the Journal may be obtained from the Hon. Treasurer, Mr. D. Chilton, Science Museum, South Kensington, London, S.W.7.

The British Fournal for the History of Science is published by the Society. Four parts constitute one Volume; each part contains approximately $9^{6}$ pages. The cover of each issue has a consecutive number for ease of collation in subsequent binding, e.g. No. 16 will be numbered: Vol. Iv Part Iv No. I6, and No. 17 will be: Vol. v Part I No. I 7 .

Order Forms, with lists of contents of Parts already published, are obtainable from the Hon. Publications Secretary, Dr. F. D. North, 39 Wellington Square, Oxford, to whom Orders for the Journal should be sent.

Whole Cloth Binding Cases lettered in Gold on spine and particulars of binding costs may be obtained from Headley Brothers Ltd., InVicta Press, AsHFORD, KeNT. 


\section{THE BRITISH JOURNAL FOR THE HISTORY OF SCIENCE}

\section{$\begin{array}{llll}\text { Volume III } & \text { Part I June } 1966 \text { No. } 9\end{array}$}

Thackray, Arnold W.-The Emergence of Dalton's

Chemical Atomic Theory: 1801-08

Hall, A. Rupert-Mechanics and the Royal Society, I668-70

ThÉODORIDÈs, JEAN—Humboldt and England

North, J. D.-Notes and Communications: Werner, Apian, Blagrave and the Meteoroscope

LAY-Yong, LAM-On the Chinese Origin of the Galley Method of Arithmetical Division

Obituary

Centenary Celebrations

Essay Reviews

Book Reviews

Books Received

PUBLISHED BY THE BRITISH SOCIETY FOR THE HISTORY OF SCIENGE

Registered Office: Science Museum, South Kensington, London, S.W.7

Brit. J. Hist. Sci. 3 no. 9. Price $£$ I Is. Free to Members of the Society. Published June I966 